\title{
Activation of CPP32-Like Caspases Contributes to Neuronal Apoptosis and Neurological Dysfunction after Traumatic Brain Injury
}

\author{
Alexander G. Yakovlev, Susan M. Knoblach, Lei Fan, Gerard B. Fox, Randyll Goodnight, and Alan I. Faden \\ Georgetown Institute for Cognitive and Computational Sciences and Department of Neurology, Georgetown University \\ Medical Center, Washington, DC 20007
}

We examined the temporal profile of apoptosis after fluid percussion-induced traumatic brain injury (TBI) in rats and investigated the potential pathophysiological role of caspase3-like proteases in this process. DNA fragmentation was observed in samples from injured cortex and hippocampus, but not from contralateral tissue, beginning $4 \mathrm{hr}$ after TBI and continuing for at least $3 \mathrm{~d}$. Double labeling of brain with terminal deoxynucleotidyl transferase-mediated dUTP-biotin nick end labeling (TUNEL) and an antibody directed to neuronal nuclear protein identified apoptotic neurons with high frequency in both traumatized rat cortex and hippocampus. Cytosolic extracts from injured cortex and hippocampus, but not from contralateral or control tissue, induced internucleosomal DNA fragmentation in isolated nuclei with temporal profiles consistent with those of DNA fragmentation observed in vivo. Caspase-3 mRNA levels, estimated by semiquantitative RT-PCR, were el- evated fivefold in ipsilateral cortex and twofold in hippocampus by $24 \mathrm{hr}$ after TBI. Caspase-1 mRNA content also was increased after trauma, but to a lesser extent in cortex. Increased caspase-3-like, but not caspase-1-like, enzymatic activity was found in cytosolic extracts from injured cortex. Intracerebroventricular administration of z-DEVD-fmk-a specific tetrapeptide inhibitor of caspase-3-before and after injury markedly reduced post-traumatic apoptosis, as demonstrated by DNA electrophoresis and TUNEL staining, and significantly improved neurological recovery. Together, these results implicate caspase-3-like proteases in neuronal apoptosis induced by TBI and suggest that the blockade of such caspases can reduce post-traumatic apoptosis and associated neurological dysfunction.

Key words: brain trauma; apoptosis; caspase-3; mRNA; PCR; neuron; immunofluorescence
Tissue damage after brain trauma results from both direct mechanical injury and secondary autodestructive reactions (Faden, 1996). Secondary injury involves a cascade of biochemical changes that contribute to delayed tissue damage and cell death (Faden, 1996). Although the focus of research on secondary brain injury historically has been on mechanisms related to necrosis (Trump and Bulger, 1967), recent studies have suggested a potential role for apoptosis in cell loss after stroke, spinal cord injury, or traumatic brain injury (TBI) (Linnik et al., 1993; MacManus et al., 1993; Kihara et al., 1994; Sei et al., 1994; Beilharz et al., 1995; Hill et al., 1995; Islam et al., 1995; Iwai et al., 1995; Li et al., 1995a,b; Rink et al., 1995; Hara et al., 1997).

Apoptosis and necrosis can be distinguished histologically (Kerr et al., 1972). Tissue necrosis is typified by loss of membrane integrity, morphological signs of organelle damage, nuclear flocculation, loss of lysosomal contents, cellular swelling, and uncontrolled cell lysis (Trump et al., 1982; Bredesen, 1995). Apoptosis is characterized by preservation of membrane integrity, cytoplasmic and nuclear condensation, diminution of cellular volume, plasma membrane bleb formation, and morphological preservation of organellar structure. The cell eventually fragments into apoptotic bodies that are engulfed by neighboring cells and de-

Received April 22, 1997; revised July 2, 1997; accepted July 23, 1997.

This study was supported by a cooperative research agreement Department of Defense Grant (DAMD-17-93-V-3018)

Correspondence should be addressed to Dr. Alexander G. Yakovlev, Research Building, EP-20, Georgetown University Medical Center, 3970 Reservoir Road, NW, Washington, DC 20007.

Copyright (C) 1997 Society for Neuroscience $\quad 0270-6474 / 97 / 177415-10 \$ 05.00 / 0$ graded (Bursch et al., 1990; Cohen, 1993; Schwartzman and Cidlowski, 1993). During apoptosis, morphological changes often are accompanied by internucleosomal cleavage of genomic DNA (Wyllie, 1980; Compton, 1992). In contrast to necrosis, apoptosis does not result in a loss of cellular content and does not initiate an inflammatory response.

Although a potential role for apoptosis in neuronal cell death after TBI has been suggested, little is known about the molecular mechanisms involved. However, activation of cysteine proteases has been implicated in apoptosis. The ced-3 gene, initially identified in Caenorhabditis elegans, promotes apoptosis during development of the nematode; the first mammalian counterpart identified was the gene encoding the interleukin- $1 \beta$-converting enzyme (ICE), a cysteine protease that activates prointerleukin- $\beta$ (Thornberry et al., 1992; Yuan et al., 1993). Numerous Ced-3-related cysteine proteases, now called caspases, have been cloned (Alnemri et al., 1996). This growing multigene family can be divided into two distinct phylogenic subfamilies: caspase-1-like and caspase-3-like proteases. Those related to caspase- 1 include caspase-1, caspase-4 (Faucheu et al., 1995; Kamens et al., 1995; Munday et al., 1995), and caspase-5 (Munday et al., 1995; Faucheu et al., 1996) Those similar to caspase-3 (Fernandes-Alnemri et al., 1994; Nicholson et al., 1995; Tewari et al., 1995) include caspase-2 (Kumar et al., 1994; Wang et al., 1994), caspase-3, and caspases-6-10 (FernandesAlnemri et al., 1995a,b, 1996; Duan et al., 1996; Lippke et al., 1996; Muzio et al., 1996).

The involvement of caspases in mammalian cell death has been established by the use of inhibitors such as the cowpox virus CrmA protein, baculovirus p35 protein, certain peptide methyl 
ketones, and specific peptide aldehydes (Clem et al., 1991; Gagliardini et al., 1994; Martin and Green, 1995). Inhibition of caspases by peptides and by gene replacement has suggested that these enzymes play a central role in apoptosis induced by different insults (Martin and Green, 1995), including serum and potassium deprivation in cerebellar granule cells (Miller and Johnson, 1996; Schultz et al., 1996; Eldadah et al., 1997), Fas and TNF $\alpha$ mediated apoptosis in white blood cells (Miura et al., 1993; Kuida et al., 1995; Los et al., 1995), and in apoptosis after serum or growth factor deprivation (Gagliardini et al., 1994; Srinivasan et al., 1996) or loss of contact with extracellular matrix (Boudreau et al., 1995). In this report we examined apoptosis after fluid percussion-induced TBI and investigated the potential role of caspase- 1 and caspase-3-like proteases in this process.

\section{MATERIALS AND METHODS}

Brain trauma model. Male Sprague Dawley rats $(425 \pm 25 \mathrm{gm})$ were anesthetized with sodium pentobarbital $(70 \mathrm{mg} / \mathrm{kg}$, i.p.). The animals were ventilated and placed in a stereotaxic frame; the scalp and temporal muscle were reflected, and a hollow female Luer-Loc fitting $(4.5 \mathrm{~mm})$ was fixed rigidly with dental cement to the animal's skull through a craniotomy centered over the left parietal cortex, $5 \mathrm{~mm}$ from the lambda and $4 \mathrm{~mm}$ from the sagittal suture. The dura was left intact. Brain injury was performed, using a lateral fluid percussion model as previously described (McIntosh et al., 1989), in which brief displacement and deformation of brain result from the rapid epidural injection of saline into the closed cranial cavity. Animals were subjected to a 2.0 or $2.6 \mathrm{~atm}$ pressure pulse, which in our model produces moderate or severe tissue damage, respectively, in ipsilateral cerebral cortex and hippocampus (Sun and Faden, 1995). Intracerebroventricular injections were performed with an indwelling catheter that was placed into the lateral ventricle ipsilateral to the injury site and permanently secured to the overlying skull. DMSO $(5 \mu \mathrm{l})$ vehicle or z-DEVD-fmk $(160 \mathrm{ng}$ in $5 \mu \mathrm{l}$ of DMSO) was administered at a controlled rate of $0.5 \mu \mathrm{l} / \mathrm{min}$ via an infusion pump at $30 \mathrm{~min}$ before and at 6 and $24 \mathrm{hr}$ after TBI. At the designated time periods after injury, animals were decapitated under sodium pentobarbital anesthesia $(100 \mathrm{mg} / \mathrm{kg}$, i.p.), and the brains were removed rapidly and dissected according to the method of Glowinski and Iversen (1966). Sham-operated (control) animals received anesthesia and surgery but were not subjected to trauma. Tissue samples were collected $1,4,12,24$, and $72 \mathrm{hr}$ after TBI. Samples were frozen on dry ice and kept at $-85^{\circ} \mathrm{C}$.

Analysis of DNA fragmentation. Apoptotic DNA was isolated and labeled as previously described (Eldadah et al., 1996), with minor modifications. In brief, genomic DNA was extracted from control or injured cortex (isolated 1, 4, 12, 24, and $72 \mathrm{hr}$ after TBI); $50-100 \mathrm{mg}$ of tissue was lysed in $0.5 \mathrm{ml}$ of $7 \mathrm{M}$ guanidine hydrochloride and centrifuged at $10,000 \times g$ for $15 \mathrm{~min}$. Supernatants were mixed with $1 \mathrm{ml}$ of Wizard Maxipreps Resin (Promega, Madison, WI), and the suspension was pelleted by centrifugation at $10,000 \times g$ for $5 \mathrm{~min}$, resuspended in $1 \mathrm{ml}$ of washing solution ( $90 \mathrm{~mm}$ sodium chloride, 9 mm Tris-HCl, $\mathrm{pH}$ 7.4, 2.25 mM EDTA, and 55\% ethanol), and drawn by vacuum through Wizard Midicolumns (Promega). Columns were washed with $6 \mathrm{ml}$ of washing solution and dried by centrifugation over a microf uge tube at $10,000 \times$ $g$ for 2 min. DNA was eluted with $50 \mu \mathrm{l}$ of $\mathrm{H}_{2} \mathrm{O}$. Residual RNA was removed by incubation with $1 \mu \mathrm{g}$ of RNase A at $37^{\circ} \mathrm{C}$ for $30 \mathrm{~min}$. DNA $(1 \mu \mathrm{g})$ was added to each $20 \mu \mathrm{l}$ of labeling mixture, which contained 10 mm Tris-HCl, $\mathrm{pH} 9.0,50 \mathrm{~mm} \mathrm{KCl}, 0.1 \%$ Triton X-100, $10 \mathrm{~mm} \mathrm{MgCl}_{2}$, 2 $\mu \mathrm{Ci}\left[\alpha^{-3} \mathrm{P}\right] \mathrm{dATP}(3000 \mathrm{Ci} / \mathrm{mmol}$; Amersham, Arlington Heights, IL), and $1 \mathrm{U}$ Taq DNA polymerase. Reactions were incubated at $72^{\circ} \mathrm{C}$ for 20 min and terminated by the addition of gel loading buffer. Samples were loaded onto a $1.5 \%$ agarose gel in Tris-Borate-EDTA running buffer and electrophoresed at $4 \mathrm{~V} / \mathrm{cm}$. Labeled DNA fragments were visualized by autoradiography of the dried gel.

Immunohistochemistry. Coronal $7 \mu \mathrm{m}$ cryosections containing the dorsal hippocampus were cut from anterior to posterior stereotaxic levels -3.6 to $-3.8 \mathrm{~mm}$ relative to bregma and thaw-mounted onto aminoalkylsilated slides. The sections were immersion-fixed in $10 \%$ buffered formalin, $\mathrm{pH} 7.1$, at room temperature $\left(22^{\circ} \mathrm{C}\right)$ for $5 \mathrm{~min}$, rinsed twice for 10 min with PBS (10 mM phosphate buffer, $2.7 \mathrm{~mm} \mathrm{KCl}$, and $137 \mathrm{~mm}$ $\mathrm{NaCl}, \mathrm{pH} 7.4$ ), and then permeabilized in $0.1 \%$ saponin (Calbiochem, $\mathrm{La}$ Jolla, CA) solution in PBS for 15 min. To identify neuronal nuclei and, to a lesser degree, neuronal cytoplasm, we gave the sections a further two 10 min washes in PBS and incubated them in a humidified chamber at room temperature with mouse $\mathrm{IgG}$ antineuronal nuclear protein $(\mathrm{NeuN}$, 1:100; Chemicon, Temecula, CA) in a PBS incubation buffer containing $1 \%(\mathrm{w} / \mathrm{v})$ bovine serum albumin (Sigma, St. Louis, MO) and $1 \%(\mathrm{v} / \mathrm{v})$ normal goat serum (Sigma). After $20 \mathrm{hr}$, the sections were washed $(2 \times$ $10 \mathrm{~min}$ ) in PBS and processed for terminal deoxynucleotidyl transferasemediated dUTP-biotin nick end labeling (TUNEL) labeling by the TACS2 TdT kit (Trevigen, Gaithersburg, MD). Initially, sections were washed for $5 \mathrm{~min}$ with the Trevigen proprietary labeling buffer, followed by a $1 \mathrm{hr}$ incubation at $37^{\circ} \mathrm{C}$ with the labeling solution containing TdT $(0.03 \mathrm{U} / \mu \mathrm{l})$, biotinylated $\mathrm{dNTP} \operatorname{mix}(0.4 \mathrm{~mm})$, and $0.25 \mathrm{~mm}$ cobalt chloride. Next, sections were washed in the stop buffer ( $0.1 \mathrm{M}$ EDTA, pH 8.0 ) for $5 \mathrm{~min}$, followed by two $10 \mathrm{~min}$ washes in $0.1 \mathrm{M}$ Tris-buffered saline (TBS) and a $1 \mathrm{hr}$ incubation at room temperature with the appropriate secondary antibodies-avidin-fluorescein isothiocyanate (FITC, 1:50; Vector, CA) for TUNEL and goat anti-mouse IgG Texas Red (TR, 1:100; Sigma) for NeuN. After three further 10 min washes in TBS, all sections were incubated for 1 min with a 1:5000 dilution of 10 $\mathrm{mg} / \mathrm{ml}$ bis-benzimide (Hoechst 33258) in PBS to resolve nuclei, mounted in Citifluor (Ted Pella, Redding, CA), and observed with an Olympus AH-2 fluorescence microscope with excitation/emission wavelengths of 345/425 (Hoechst), 490/525 (FITC), and 590/615 (TR). Primary antibody, TdT and TdT-dNTP mix, or secondary antibody were omitted in control sections.

Reverse transcription-PCR. The levels of mRNA were analyzed with an RT-PCR approach, as previously described (Yakovlev and Faden, 1994, 1995). In brief, total cellular RNA was isolated by acidic phenol extraction (Chomczynski and Sacchi, 1987) and $5 \mu \mathrm{g}$ of it was reverse-transcribed with M-MLV RT (Life Technologies, Gaithersburg, MD) in $20 \mu$ l of reaction mixture. The resulting cDNA $(3 \mu \mathrm{l})$ was amplified by PCR. The numbers of cycles and reaction temperature conditions were estimated to be optimal to provide a linear relationship between the amount of input template and the amount of PCR product generated over a wide concentration range: from 0.5 to $10 \mu \mathrm{g}$ of total RNA, as described in detail previously (Yakovlev and Faden, 1994). Primers to amplify the rat caspase-1 cDNA were 5'CACATTGAAGTGCCCAAGCT-3' (sense primer, positioned at $795 \mathrm{nt}$ according to GenBank sequence U14647) and 5'-TCCAAGTCACAA GACCAGGC-3' (antisense primer, positioned at 1094 nt according to GenBank sequence U14647). Primers to amplify rat caspase-3 cDNA were 5'-GGTATTGAGACAGACAGTGG-3' (sense primer, positioned at 601 nt according to GenBank sequence U58656) and 5'-CATGGGATCTGT TTCTTTGC-3' (antisense primer, positioned at $881 \mathrm{nt}$ according to GenBank sequence U58656). Both cDNA were amplified for 35 cycles, consisting of denaturing for $30 \mathrm{sec}$ at $94^{\circ} \mathrm{C}$, annealing for $15 \mathrm{sec}$ at $55^{\circ} \mathrm{C}$, and primer extension for $45 \mathrm{sec}$ at $72^{\circ} \mathrm{C}$. Amplified cDNA was analyzed in 3\% agarose electrophoretic gels. After being stained with ethidium bromide, UV light gel images were captured and analyzed by the Image 1.59 program. Levels of individual mRNA were expressed in arbitrary units as the proportion of individual PCR product mean optical density (inverted video image) to a control product mean optical density obtained from the same RNA sample. The cDNA for GAPDH was used as the internal control because its levels remain constant in different models tested. Primers to amplify rat GAPDH cDNA were 5'-TAAAGGGCATCCTG GGCTACACT-3' (sense primer, positioned at 833 nt according to GenBank sequence M17701) and 5'-TTACTCCTTGGAGGCCATGTA GG-3' (antisense primer, positioned at 1032 nt according to GenBank sequence M17701). GAPDH cDNA was amplified for 22 cycles at PCR conditions described for caspase- 1 and caspase- 3 cDNA. The identity of each PCR-generated product to a corresponding cDNA was confirmed by the subcloning in pCR2.0 TA cloning vector (Invitrogen, San Diego, CA) and the sequencing of the inserts by chain termination reaction with SP6 and $\mathrm{T} 7$ sequencing primers.

In vitro DNA fragmentation assay. Sham-operated and injured rat cortex were homogenized in a Dounce homogenizer in $10 \mathrm{~mm} \mathrm{HEPES/}$ $\mathrm{KOH}, \mathrm{pH}$ 7.2, 2 mM EDTA, 0.1\% CHAPS, $5 \mathrm{~mm}$ dithiothreitol, $1 \mathrm{~mm}$ phenylmethylsulphonyl fluoride, $10 \mu \mathrm{g} / \mathrm{ml}$ pepstatin A, $20 \mu \mathrm{g} / \mathrm{ml}$ leupeptin, and $10 \mu \mathrm{g} / \mathrm{ml}$ aprotinin (Nicholson et al., 1995). Homogenates were centrifuged at $13,000 \times g$ for $30 \mathrm{~min}$. Supernatants were transferred to new tubes and stored at $-85^{\circ} \mathrm{C}$ until used. Protein concentration was estimated by the Bradford method (Bio-Rad, Hercules, CA) according to recommendations by the manufacturer.

Nuclei were prepared from rat liver (Newmeyer and Wilson, 1991). In brief, minced liver was homogenized in the buffer [(in mM) 15 PIPES$\mathrm{NaOH}, \mathrm{pH}$ 7.4, $80 \mathrm{KCl}, 15 \mathrm{NaCl}, 5$ EDTA, 1 DTT, 0.5 spermidine, 0.2 


\section{Cortex}

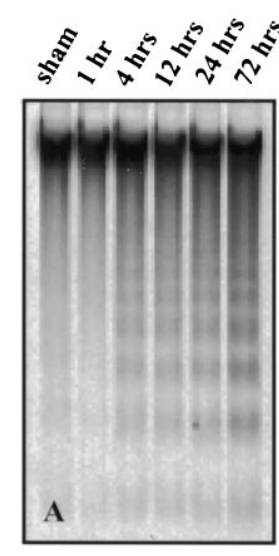

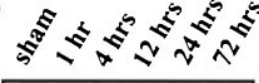

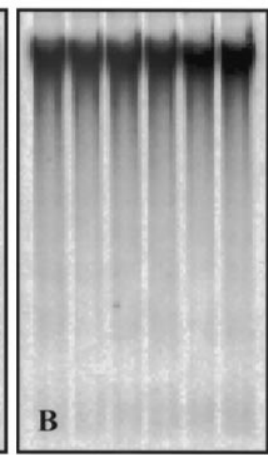

H i p p o c a m p u s

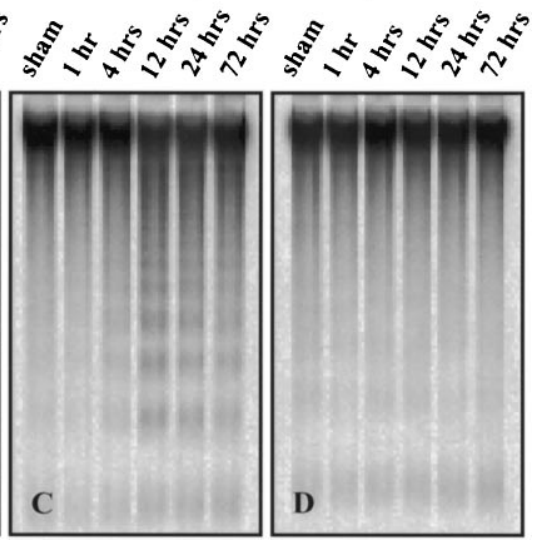

Figure 1. Agarose gel electrophoretic analysis of genomic DNA from traumatized $(A, C)$, contralateral $(B, D)$, and sham-operated rat cortex $(A, B)$ and hippocampus $(C, D)$. Total DNA was isolated at indicated times after TBI. One microgram of DNA from each sample was labeled with $\left[\alpha^{32} \mathrm{P}\right]$ dATP, using Taq DNA polymerase, and analyzed in $1.5 \%$ agarose gel. Dried gel was exposed with x-ray film and photographed. Data are representative of three separate experiments with similar results. spermine, and 1 PMSF) containing $250 \mathrm{~mm}$ sucrose in a Dounce homogenizer. After filtration through four layers of cheesecloth, an equal volume of the buffer containing $2.3 \mathrm{M}$ sucrose was added and mixed. Then homogenates were layered over $10 \mathrm{ml}$ of the buffer containing $2.3 \mathrm{M}$ sucrose in a Beckman SW28 centrifuge tube and centrifuged at 22,000 $\mathrm{rpm}$ for $90 \mathrm{~min}$ at $4^{\circ} \mathrm{C}$. The pellet was resuspended in homogenization buffer containing $50 \%$ glycerol at a concentration of 3-7 $\times 10^{7}$ nuclei $/ \mathrm{ml}$ and stored at $-85^{\circ} \mathrm{C}$ (Enari et al., 1995).

The reaction mixtures contained (in mM) 10 HEPES, pH 7.0, $50 \mathrm{NaCl}$, $3 \mathrm{MgCl}_{2}$, 5 EGTA, 1 DTT, 3 ATP, and 10 creatine phosphate, with 50 $\mu \mathrm{g} / \mathrm{ml}$ creatine kinase, various amounts of the tissue extracts, and $5 \times$ $10^{5}$ nuclei in a final volume of $60 \mu$ l. The mixtures were incubated at $37^{\circ} \mathrm{C}$ for various periods. DNA from nuclei was isolated as described by Eldadah et al. (1996). Nuclei were lysed with $300 \mu$ l of 7 M guanidine hydrochloride; lysates were mixed with $1 \mathrm{ml}$ of Wizard Minipreps DNA Purification Resin (Promega) and drawn by vacuum through a Wizard Midicolumn (Promega). The column was washed with $3 \mathrm{ml}$ of washing solution and dried by centrifugation over a microf uge tube at $10,000 \times$ $g$ for $2 \mathrm{~min}$. To elute the DNA, we added $50 \mu \mathrm{l}$ of Tris-EDTA buffer, $\mathrm{pH}$ 8.0, followed by centrifugation over a new microfuge tube. Residual RNA was removed by the addition of $1 \mu \mathrm{g}$ of RNase A and incubated at $37^{\circ} \mathrm{C}$ for 30 min. DNA was analyzed by gel electrophoresis with $1.5 \%$ agarose in the presence of $0.5 \mu \mathrm{g} / \mathrm{ml}$ ethidium bromide.

Assay for caspase activity. Assay for CPP32- or caspase-1-like activity was performed as described by Nicholson et al. (1995) with minor modification. Aliquots of cytosolic extracts $(25 \mu \mathrm{g}$ of protein in $100 \mu \mathrm{l}$ of extraction buffer) were preincubated at $37^{\circ} \mathrm{C}$ for $30 \mathrm{~min}$ and then mixed with equal volumes of $40 \mu \mathrm{M}$ fluorescent tetrapeptide substrate (AcDEVD-AMC or Ac-YVAD-AMC; Bachem, Torrance, CA) in the same buffer solution. Free aminomethylcoumarin (AMC) accumulation, which resulted from cleavage of the aspartate-AMC bond, was monitored continuously in each sample over $30 \mathrm{~min}$ in 96-well microtiter plates, using a CytoFluor II fluorometer (PerSeptive Biosystems, Framingham, $\mathrm{MA})$ at $360 \mathrm{~nm}$ excitation and 460 emission wavelengths. The emission from each well was plotted against time. Linear regression analysis of the initial velocity (slope) of each curve yielded an activity for each sample. Data were expressed as a percentage of the caspase activity in samples from sham-operated control animals.

Neurological scoring. Neuroscores reflect a composite of separate functional evaluations, including resistance to forced lateral pulsion (right and left), forelimb contraflexion on suspension by the tail (right and left), and ability to maintain position on an inclined plane (right, left, and vertical). These tests show high interobserver reliability, and we have used them in a number of studies to discriminate treatment effects (Faden et al., 1989; Sun and Faden, 1995). Animals were rated from 0 (no function) to 5 (normal function) for each test, with a maximum possible composite score of 35. Evaluations were conducted by an individual unaware of treatment, who used procedures detailed previously (Sun and Faden, 1995). With the level of trauma used, improvement typically is observed in untreated animals over the first 2 weeks, after which the deficits stabilize. Treatment effects for neuroprotective agents usually are seen by 1 week, with maximal differences versus controls by 2 weeks (Faden, 1993).

Data analysis. Changes in mRNA content and activity for caspase-3 and caspase-1-like proteases were analyzed by ANOVA, followed by
Dunnett's test. Neuroscores were compared with Kruskal-Wallis ANOVA, followed by individual nonparametric Mann-Whitney $U$ tests. A $p$ value $<0.05$ was considered statistically significant.

\section{RESULTS}

\section{Induction of apoptosis after fluid percussion-induced TBI}

The induction of apoptosis in cortex and hippocampus of rat brains subjected to experimental TBI was examined by electrophoretic analysis of internucleosomal DNA fragmentation and the TUNEL method. Agarose gel electrophoresis of labeled DNA isolated from rat cortex and hippocampus demonstrated fragmentation of DNA in affected areas of the injured brain (Fig. 1). DNA fragmentation from samples of injured cortex or hippocampus, but not from contralateral cortex or hippocampus, was detected beginning $4 \mathrm{hr}$ after trauma. Marked DNA laddering was observed up to $3 \mathrm{~d}$, the last time point examined in these experiments.

To verify further an apoptotic component of post-traumatic cell death, we used the TUNEL staining technique on tissue sections from injured or control rat brains. TUNEL-positive cells with shrunken morphology, condensed nuclei, chromatin margination, and formation of apoptotic bodies were detected in the ipsilateral injured parietotemporal cortex as early as $6 \mathrm{hr}$ postinjury. The number of these apoptotic cells was greatly increased at 24 and $72 \mathrm{hr}$. No TUNEL-positive cells were observed in the contralateral cortex or in sham-operated animals. Extensive TUNEL immunoreactivity also was observed in the subcortical white matter, the hippocampal CA1, CA2, and CA3 pyramidal cell regions, the border between the granule cell layer and hilus, and the dorsal blade of the granule cell layer itself. In addition, a smaller number of cells in the polymorph layer of the dentate gyrus were also immunopositive. These findings subsequently were extended to identify TUNEL-positive neurons, using double labeling of brain sections with TUNEL and antibodies recognizing neuronal nuclear protein. Double immunofluorescence staining demonstrated a large proportion of the TUNEL-positive cells to be neurons (shown for parietotemporal cortex in Fig. $2 A-F)$.

\section{Reconstitution of post-traumatic apoptosis in vitro}

To examine further the induction of post-traumatic apoptosis, we used a recently developed model of reconstitution of this process in vitro (Lazebnik et al., 1993; Enari et al., 1995; Martin et al., 1995). Protein extracts isolated from traumatic rat cortex were able to induce the internucleosomal fragmentation of DNA in 

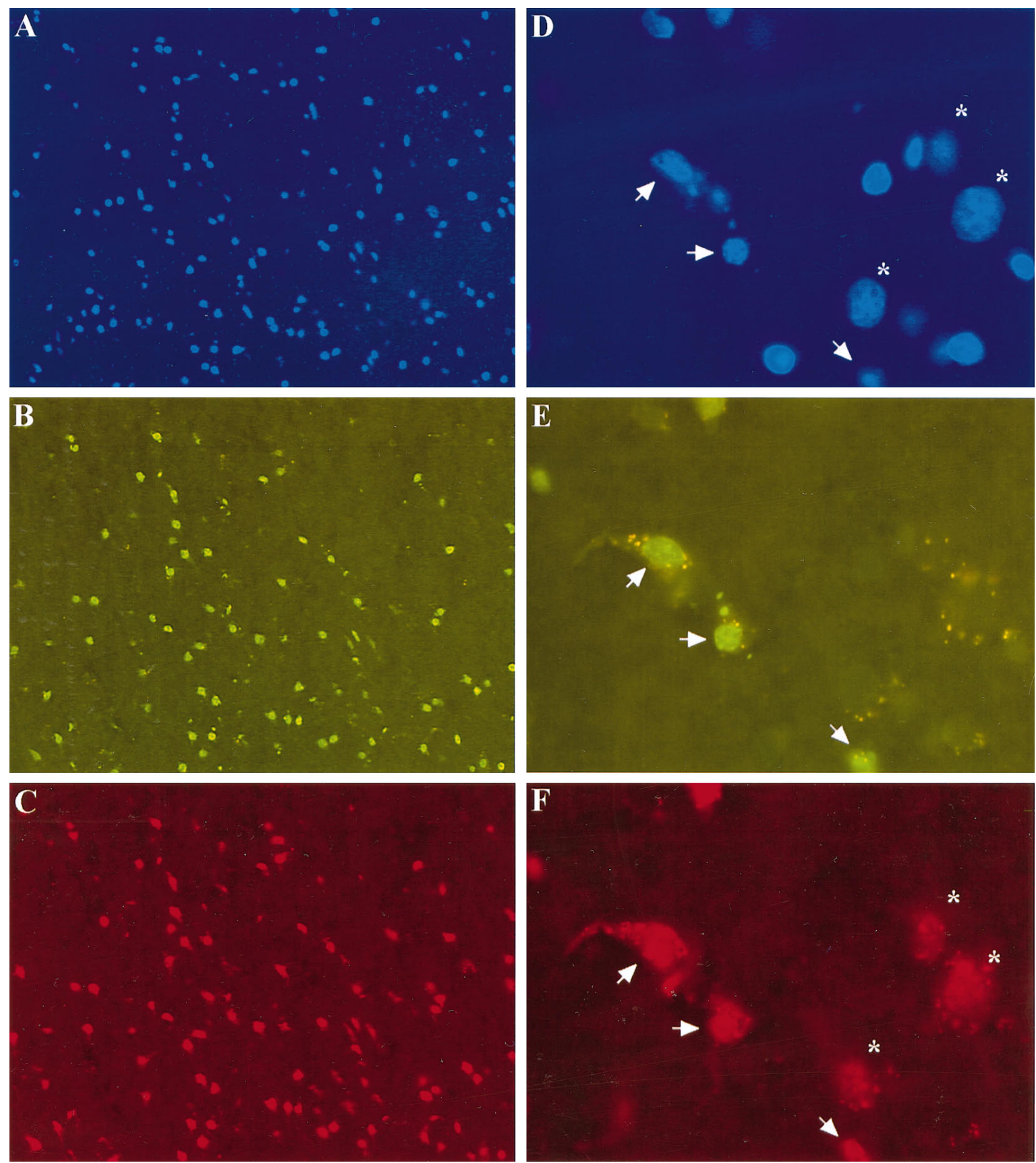

Figure 2. Identification of TUNEL-positive neurons in the rat parietotemporal cortex $24 \mathrm{hr}$ after TBI. Photographs at the left of the figure $(A-C)$ represent $100 \times$ magnification; photographs to the right of the figure $(D-F)$ represent $400 \times$ magnification. The same microscopic fields were stained with Hoechst $33258(A, D)$, TUNEL $(B, E)$, and antineuronal nuclear protein $(C, F)$. Many TUNEL-positive cells exhibited the morphology of apoptotic cells (arrows in $D, E$ ). Double immunofluorescence for TUNEL and antineuronal nuclear protein revealed a majority of these cells to be neurons (arrows in $E, F)$. Note the three neurons (asterisks in $D, F)$ that did not stain with TUNEL $(E)$ and the presence of additional non-neuronal cells $(D)$, which were also TUNEL-negative $(E)$.

isolated nuclei. This process depended on the concentration of a protein extract in incubation mixtures and the incubation time with a peak DNA cleavage ability for an extract isolated from injured cortex $3 \mathrm{~d}$ after trauma at a concentration of protein of 0.4 $\mathrm{mg} / \mathrm{ml}$ (Fig. 3A). Interestingly, the increase of extract concentration in the reaction mixture to $0.8 \mathrm{mg} / \mathrm{ml} \mathrm{led} \mathrm{to} \mathrm{a} \mathrm{reduction} \mathrm{in}$ DNA fragmentation. This observation may suggest the existence, in cellular extracts, of an endogenous inhibitor of the apoptotic process. Fragmentation of DNA in vitro was observed by $15 \mathrm{~min}$ and increased progressively during the incubation time (Fig. $3 B$ ).
A study of the assay components showed that observed DNA fragmentation was dependent on the presence of ATP and an energy-regenerating system but that $\beta$-glycerophosphate, recommended in the assay by some authors, was not required and actually inhibited the process (data not shown).

Agarose gel electrophoretic analysis indicated that the degree of DNA fragmentation in vitro induced by extracts from injured cortex and hippocampus was consistent with the in vivo experiments (Fig. 4). Thus, the incubation of nuclei with extracts from sham controls did not result in detectable fragmentation of DNA, 
Protein concentration $(\mathrm{mg} / \mathrm{ml})$

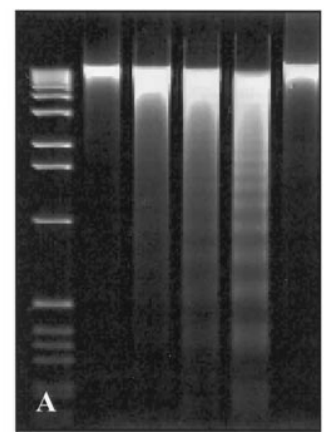

$\begin{array}{llllll}\text { MW } & 0 & 0.1 & 0.2 & 0.4 & 0.8\end{array}$
Incubation time (min)

MW $0 \begin{array}{lllll}15 & 30 & 45 & 60\end{array}$

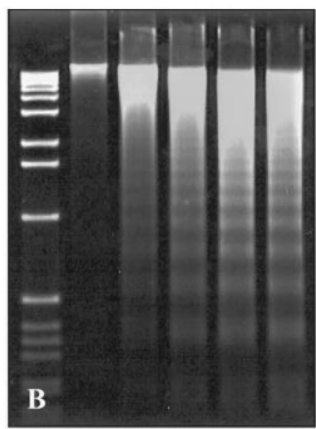

Figure 3. Dose dependence $(A)$ and time course $(B)$ of in vitro DNA fragmentation in isolated normal rat liver nuclei induced by cytosolic extracts from traumatized rat cortex at $72 \mathrm{hr}$ after TBI. $A$, Nuclei were incubated with serial dilutions of the cortical extract at $37^{\circ} \mathrm{C}$ for $60 \mathrm{~min}$, as described in Materials and Methods. $B$, Nuclei were incubated with 0.4 $\mathrm{mg} / \mathrm{ml}$ cytosolic extract for the indicated periods of time at $37^{\circ} \mathrm{C}$. DNA isolated from nuclei was analyzed by gel electrophoresis in $1.5 \%$ agarose in the presence of $0.5 \mu \mathrm{g} / \mathrm{ml}$ ethidium bromide. Two separate experiments with similar results were performed. The standard DNA fragments $(M W)$ represent a $1 \mathrm{~kb}$ DNA ladder (Life Technologies).

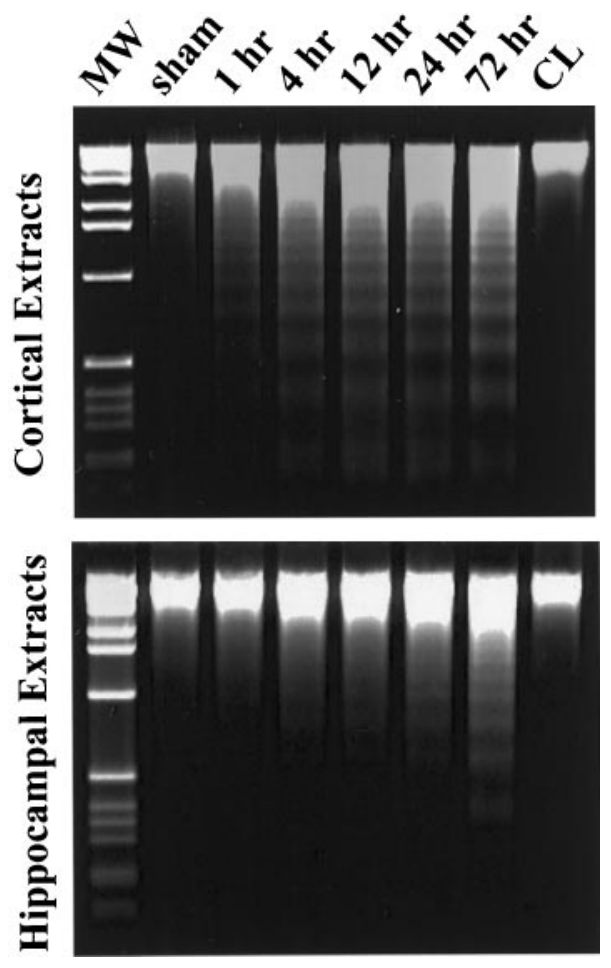

Figure 4. DNA fragmentation induced by cytosolic extracts from sham control, injured, and contralateral $(C L)$ rat cortex and hippocampus. Cytosolic extracts from injured brain tissues were isolated at indicated times after TBI; extracts from $C L$ tissues were isolated $72 \mathrm{hr}$ after TBI. Nuclei from rat normal liver were incubated with extracts, and their DNA was analyzed by agarose gel electrophoresis, as described in Materials and Methods. Data are representative of three separate experiments with similar results. The standard DNA fragments $(M W)$ represent a $1 \mathrm{~kb}$ DNA ladder.

whereas extracts from injured tissue isolated as early as $4 \mathrm{hr}$ postinjury produced DNA laddering. Maximal DNA fragmentation was observed with extracts from both ipsilateral cortex and hippocampus isolated $3 \mathrm{~d}$ after trauma. No DNA fragmentation was observed with extracts from contralateral tissue sampled at the same time. The degree of DNA fragmentation induced in vitro by extracts from injured cortex appeared to be greater than that induced by hippocampal extracts, although it should be noted that this method is not strictly quantitative.

\section{TBI-induced changes in caspase-1 and caspase-3 mRNA content and their enzymatic activity}

Activation of caspases has been implicated in apoptotic cell death in a number of models. To address the potential role of these proteases in apoptotic cell death after TBI, we measured levels of mRNA for two members of this family: caspase- 1 and caspase- 3 . mRNA levels were estimated by semiquantitative analysis with RT-PCR. Caspase-1 RT-PCR experiments were based on the rat cDNA sequence (Keane et al., 1995). For our caspase-3 RT-PCR experiments, sequence information was obtained via cloning of the corresponding cDNA (GenBank accession number U58656).

Caspase-3 mRNA levels were elevated approximately fivefold in ipsilateral cortex by $4 \mathrm{hr}$ and twofold in hippocampus at $24 \mathrm{hr}$ after trauma (Fig. 5A,B). Caspase-1 mRNA also was increased after trauma, but to a lesser extent, with a greater increase in injured hippocampus ( $\sim 230 \%$ of control level), as compared with injured cortex (150\% of control). In both regions elevation of caspase-1 mRNA was observed at later time points (72 $\mathrm{hr}$ in cortex; 24-72 hr in hippocampus) than for caspase-3 (Fig. 5C,D). Levels of caspase- 1 and caspase- 3 mRNA were unaffected in contralateral cortex or hippocampus.

To examine if the observed elevation of caspase- 3 and caspase- 1 mRNA leads to an increase in corresponding caspase activity and to address further the potential role of caspase subfamilies in post-traumatic apoptosis, we estimated posttraumatic changes in their activity levels for both cortex and hippocampus. Caspase activity was assayed for caspase-3- and caspase-1-like proteases, using the specific fluorogenic tetrapeptide substrates Ac-DEVD-AMC and Ac-YVAD-AMC, respectively. As shown in Figure 6, TBI induced a significant elevation of CPP32-like activity in extracts from injured cortex, rising to $134 \pm 4 \%$ of control levels by $3 \mathrm{~d}$ after trauma. This fluorometric assay did not detect significant changes in caspase-3-like activity in extracts from contralateral tissue or injured hippocampus. In contrast, caspase-1-like activity was found to be decreased in both injured cortex and hippocampus: $67 \pm 6 \%$ of sham levels in cortex and $68 \pm 4 \%$ in hippocampus at $24 \mathrm{hr}$, and $86 \pm 5 \%$ of sham levels in cortex at $72 \mathrm{hr}$ post-trauma. No changes in caspase-1-like activity were detected in contralateral brain regions.

\section{Effect of caspase-3 tetrapeptide inhibitors in vitro and in vivo}

To assess the potential role of CPP32-like caspases in traumamediated apoptosis, we examined the ability of the specific tetrapeptide substrate for caspase-3, z-DEVD-fmk, to inhibit TBIinduced apoptosis in vivo. The tetrapeptide administered intracerebroventricularly $30 \mathrm{~min}$ before and 6 and $24 \mathrm{hr}$ after TBI (160 ng/injection) reduced internucleosomal DNA cleavage in affected brain areas, as was shown by DNA electrophoretic analysis (Fig. $7 A$ ) and TUNEL staining (Fig. 7B). To address whether this caspase-related apoptosis was associated with functional neurological changes after injury, we examined the effects of intracerebroventricular administration of z-DEVD-fmk on motor recovery after TBI. Treatment with this caspase inhibitor significantly improved neurological outcome when compared with traumatized animals treated with DMSO vehicle $(p<0.01$; Fig. 8). 


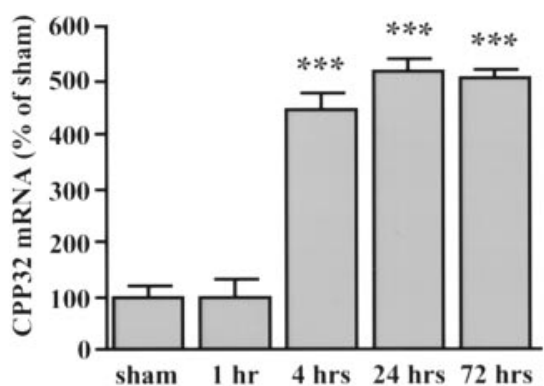

A

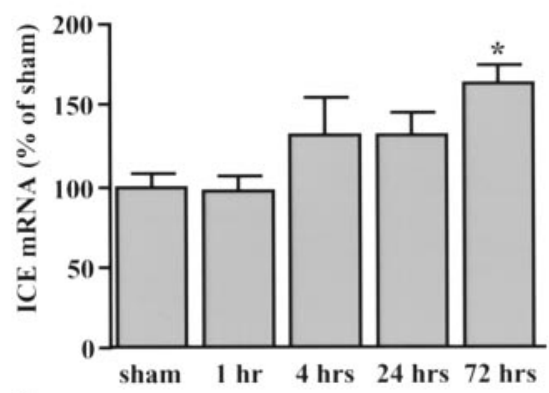

C

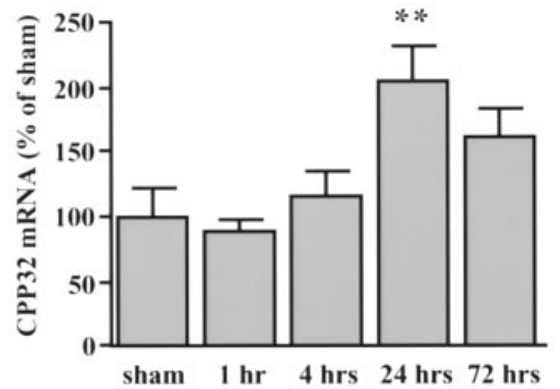

B

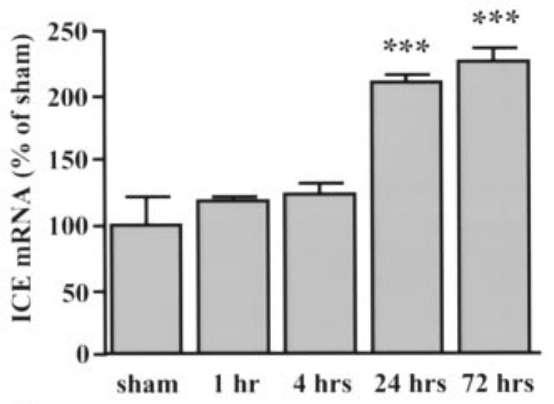

D
Figure 5. The time course of caspase-3 $(A, B)$ and caspase-1 $(C, D)$ mRNA expression in rat cortex $(A, C)$ and hippocampus $(B, D) 1,4,24$, and $72 \mathrm{hr}$ after TBI or in sham-operated controls (sham). Levels of mRNA were measured by using semiquantitative RT-PCR as the proportion of individual RT-PCR product mean optical density to GAPDH RT-PCR product optical density of the same RNA sample. mRNA content is expressed as a percentage of sham controls + SEM $(n=5) .{ }^{*} p<0.05 ; * * p$ by ANOVA and Dunnett's test.
When z-DEVD-fmk and z-YVAD-fmk were tested in the in vitro DNA fragmentation system by adding them to the extracts from traumatized cortex, shown to induce DNA fragmentation in isolated nuclei, they had little effect on DNA degradation over a wide range of concentrations from 2 to $200 \mu \mathrm{M}$ (Fig. 9). However, fragmentation of DNA in vitro clearly was inhibited by $200 \mu \mathrm{M}$ aurintricarboxylic acid, which inhibits cellular processes that depend on the formation of protein-nucleic acid complexes and which has been shown to inhibit apoptosis in a variety of experimental models (Mogil et al., 1994; Duffey et al., 1996; Kharlamov et al., 1996). In addition, complete inhibition of DNA cleavage activity was achieved by incubating cortical extracts with $20 \mu \mathrm{M}$ EDTA.

In contrast, in the in vitro assay of apoptotic reconstitution, cytosolic extracts from traumatized cortex of animals treated with z-DEVD-fmk isolated $72 \mathrm{hr}$ after trauma demonstrated marked reduction of DNA cleavage activity, as compared with DMSO vehicle-treated controls (Fig. 10).

\section{DISCUSSION}

These studies demonstrate that apoptosis plays an important pathophysiological role in post-traumatic neuronal loss and associated neurological deficits after fluid percussion-induced TBI in rats, extending the work of Rink et al. (1995) in the same model.

To address the potential role of caspase-1-like and caspase-3like proteases in TBI-induced apoptosis, we measured the levels of their corresponding mRNA and enzymatic activities after injury. Both caspase-1 and caspase-3 mRNA were induced in injured cortex and hippocampus. Caspase-1 mRNA was increased to a lesser extent but showed a relatively greater percentage increase in injured hippocampus when compared with injured cortex. In contrast, caspase-3 mRNA levels in ipsilateral cortex were two- to threefold higher than in hippocampus. Observed elevation of caspase-3, but not caspase- 1 mRNA content, was consistent with the results of caspase activity measurements that demonstrated significant progressive increases in caspase-3-like activity beginning $1 \mathrm{hr}$ after TBI.

Caspases are synthesized as inactive proenzymes that require proteolytic activation. Activation of one protease can lead to cleavage and activation of additional molecules of the same or other proteases, leading to an amplified protease cascade (Tewari et al., 1995). Activation of caspase-3 via specific cleavage by caspase-1 has been demonstrated during Fas-mediated apoptosis (Enari et al., 1996). Whether such an interaction occurs between caspase- 1 and caspase- 3 in post-traumatic apoptosis remains to be determined. However, the fact that the time course for induction of caspase- 3 and caspase- 1 mRNA was different may indicate activation of caspase- 3 by an enzyme other than caspase- 1 . Caspase-8, a protease triggering the proteolytic activation of downstream caspases and apoptosis resulting from overstimulation of p55 TNF or Fas/APO-1 receptors (Boldin et al., 1996; Muzio et al., 1996), recently has been demonstrated to cleave caspase-3 zymogen in a cell-free system (Muzio et al., 1997). Whether caspase- 8 activation occurs as a result of TBI has not been determined; however, the early induction of $\mathrm{TNF} \alpha$, the cytokine suggested to induce activation of caspase- 8 (Boldin et al., 1996), has been well documented in various models of CNS trauma (Shohami et al., 1994; Yakovlev and Faden, 1995; Buttini et al., 1996; Fan et al., 1996; Wang et al., 1996).

It has been suggested that the activation of caspase-3, followed by cleavage of specific substrates, may contribute to the process of apoptosis by structural changes or by affecting certain signaling molecules. One early biochemical event that accompanies apoptosis in many cell types is the proteolytic cleavage of nuclear proteins by caspase-3-like proteases, including poly(ADP-ribose) polymerase (PARP) (Masson et al., 1995; Nicholson et al., 1995) and DNA-dependent protein kinase (DNA-PK) (Casiola-Rosen et al., 1995). The significance of cleavage of these proteins in apoptosis currently is unknown, although PARP and DNA-PK 
A

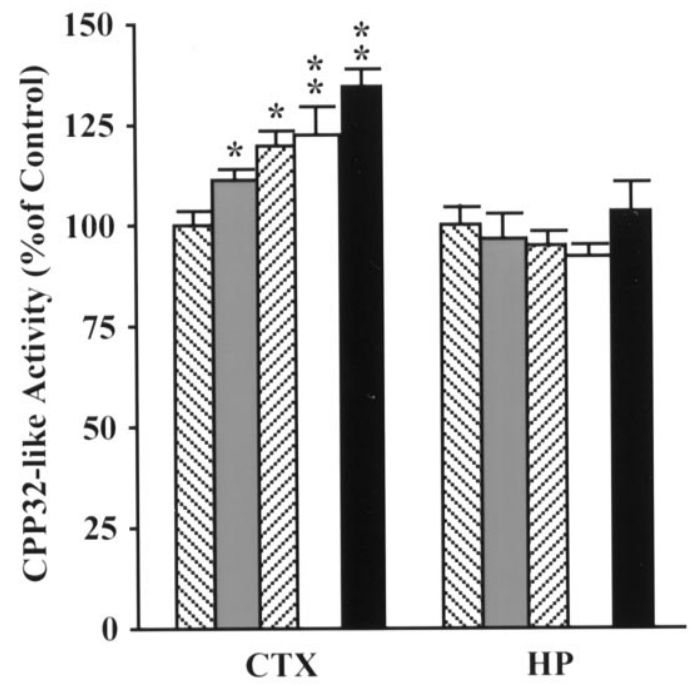

B

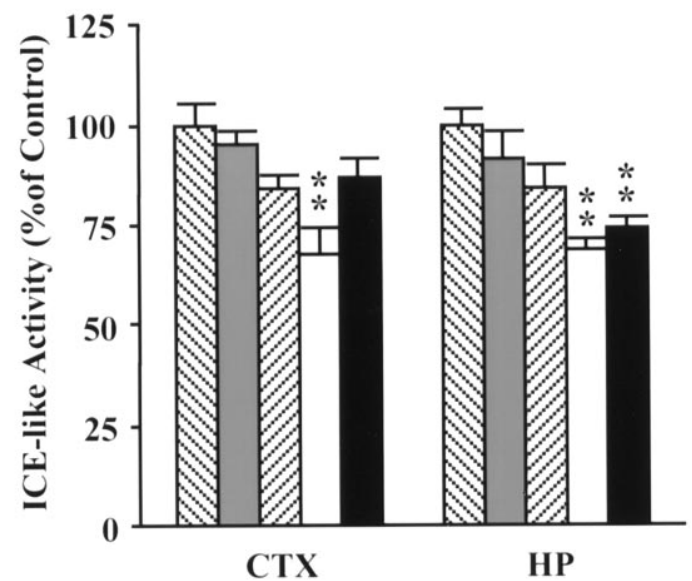

Figure 6. CPP32-like $(A)$ and caspase-1-like $(B)$ caspase activities in cytosolic protein extracts from rat traumatized cortex $(C T X)$ and hippocampus (HP) $1 \mathrm{hr}$ (shaded bars), $4 \mathrm{hr}$ (right-hatched bars), $24 \mathrm{hr}$ (open bars), and $72 \mathrm{hr}$ (filled bars) after TBI or in sham-operated controls (left-hatched bars). Cleavage of Ac-DEVD-AMC or Ac-YVAD-AMC, substrates for CPP32- or caspase-1-like proteases, respectively, were assayed fluorometrically by measuring the accumulation of free aminomethylcoumarin. Protease activity is expressed as a percentage of sham controls $+\operatorname{SEM}(n=4) .{ }^{*} p<0.05 ;{ }^{* *} p<0.01$, compared with control, by ANOVA and Dunnett's test.

are involved in DNA repair and protection of fragmented DNA (Satoh and Lindahl, 1992; Morozov et al., 1994). At least two important components of the cytoskeleton, $\beta$-actin and actinassociated protein $\alpha$-fodrin, also are cleaved during apoptosis by caspase-3-like proteases. When cleaved by caspase-3, actin loses its ability to polymerize and to inhibit DNase I activity (Mashima et al., 1995). Thus an activation of caspase-3-like enzyme or enzymes may contribute to both the morphological changes and the DNA fragmentation observed during apoptosis.

Internucleosomal DNA fragmentation occurs when cytosolic extracts prepared from apoptotic cells are combined with intact nuclei from healthy cells (Lazebnik et al., 1993; Enari et al., 1995; Martin et al., 1995). We demonstrated the relevance of this cell-free system to an in vivo model of brain trauma, because the degree of DNA fragmentation induced in vitro by cytosolic extracts from traumatized cortex and hippocampus was consistent with the temporal profile for in vivo expression of apoptosis,
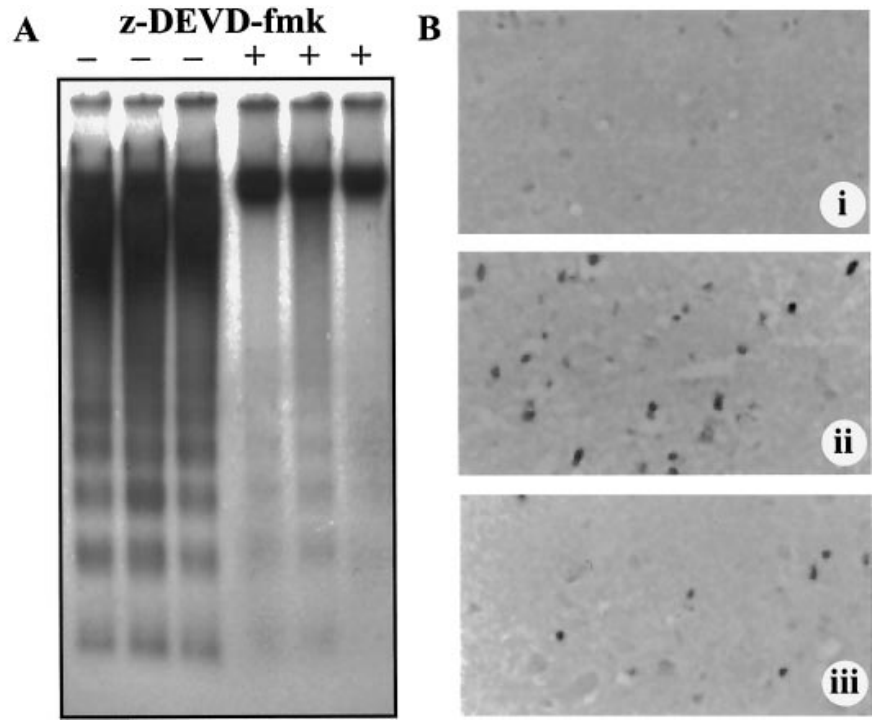

Figure 7. Effect of z-DEVD-fmk administration in vivo on internucleosomal DNA fragmentation in rat cortex after TBI. Five microliters of DMSO vehicle (-) or z-DEVD-fmk (160 ng in $5 \mu$ l of DMSO) were administered $30 \mathrm{~min}$ before and 6 and $24 \mathrm{hr}$ after TBI. $A$, Genomic DNA from injured cortex of treated with vehicle $(-)$ or z-DEVD-fmk $(+)$ rats was isolated $3 \mathrm{~d}$ after TBI. One microgram of DNA from each sample was Taq-labeled with $\left[\alpha^{32} \mathrm{P}\right]$ dATP and analyzed in a $1.5 \%$ agarose gel. The autoradiograph demonstrates DNA fragmentation patterns from three rats treated either with DMSO $(-)$ or z-DEVD-fmk $(+)$. $B$, TUNEL staining of corresponding sections from parietal cortex of a shamoperated control animal $(i)$ and traumatized brains from animals treated with DMSO vehicle (ii) or z-DEVD-fmk (iii). Cryosections fixed in formalin were stained for TUNEL, using the TACS2 TdT kit (Trevigen), and visualized by HRP/TACS blue (Trevigen). TUNEL-positive nuclei appear dark gray or black, whereas nonapoptotic nuclei appear light gray.

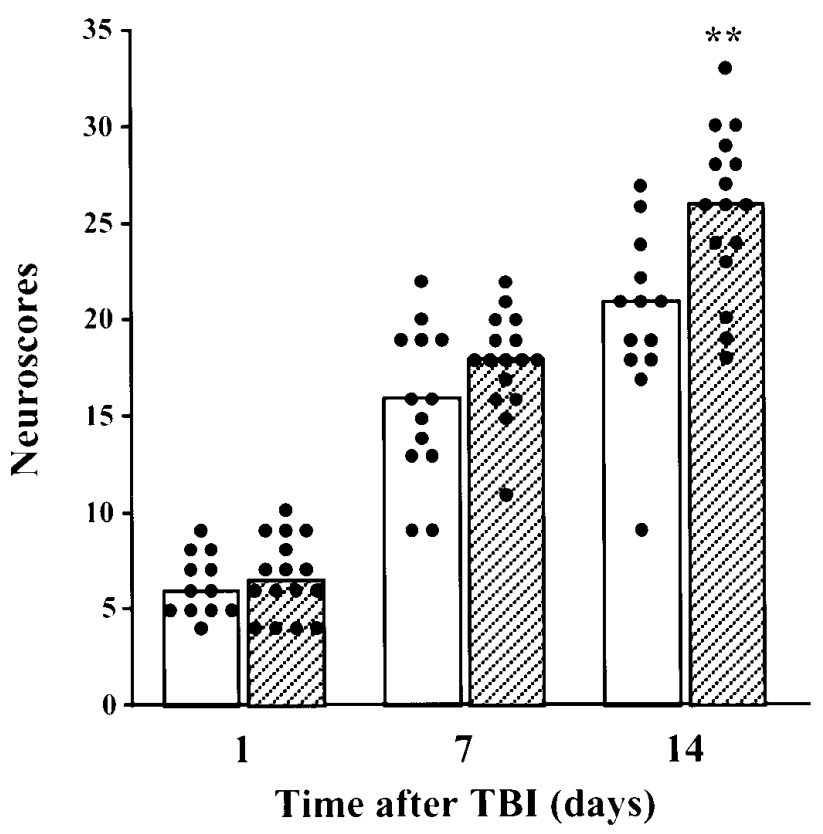

Figure 8. Effect of intracerebroventricular administration of zDEVDfmk on neurological recovery after lateral fluid percussion-induced TBI. The histogram represents median scores at indicated times after trauma. Each filled circle represents an individual animal's cumulative neuroscore, reflecting performance on a battery of motor tests. Open bars, Vehicletreated injury, $n=13$; filled bars, zDEVD-fmk-treated injury, $n=16$. ${ }_{* *}^{*} p<0.01$ versus vehicle-treated injury, using the Mann-Whitney $U$ test after Kruskal-Wallis nonparametric ANOVA. 
Figure 9. Effect of tetrapeptide inhibitors of caspases, aurintricarboxylic acid (ATA), and EDTA on in vitro fragmentation of DNA in isolated nuclei. Cytosolic extracts from injured cortex isolated $72 \mathrm{hr}$ after TBI were preincubated with different concentrations of z-DEVD-fmk (lanes 4-6), z-YVAD-fmk (lanes 7-9), ATA (lanes 10-12), $20 \mathrm{~mm}$ EDTA (lane 13), or the reaction buffer (lanes 2,3) in a final volume of $60 \mu \mathrm{l}$ at $37^{\circ} \mathrm{C}$ for $30 \mathrm{~min}$, followed by the addition of mixtures to normal rat liver nuclei. The control sample of nuclei (lane 2) was incubated in the reaction buffer without the addition of the cytosolic extract. Mixtures were incubated at $37^{\circ} \mathrm{C}$ for an additional $30 \mathrm{~min}$, and DNA isolated from nuclei was analyzed by agarose gel electrophoresis. The standard DNA fragments $(M W$; lanes 1,14$)$ represent a $1 \mathrm{~kb}$ DNA ladder.

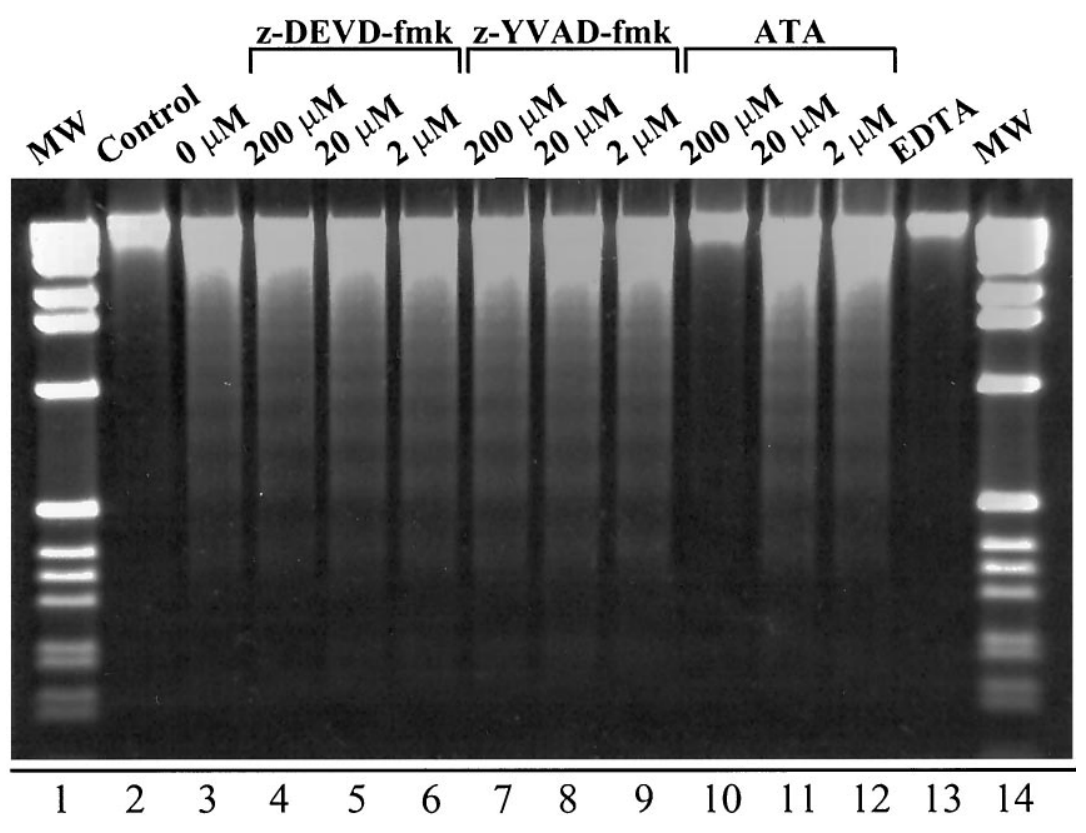

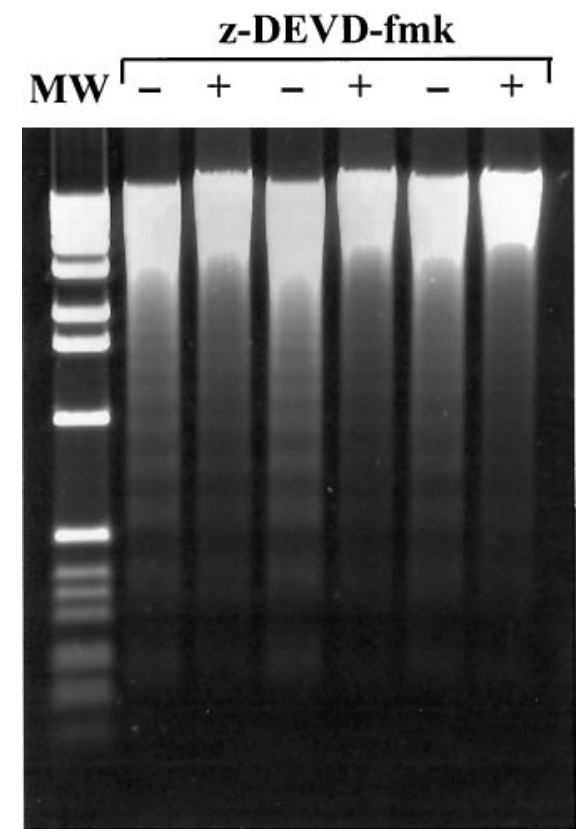

Figure 10. Effect of z-DEVD-fmk administered in vivo on internucleosomal DNA fragmentation induced in isolated nuclei by cytosolic extracts from traumatized rat cortex. z-DEVD-fmk or DMSO was administrated in vivo, as described in the legend for Figure 7. Cytosolic extracts from the injured cortex of treated animals isolated $72 \mathrm{hr}$ after TBI were incubated with liver nuclei at $37^{\circ} \mathrm{C}$ for $30 \mathrm{~min}$. DNA isolated from nuclei was analyzed by agarose gel electrophoresis. The gel demonstrates DNA fragmentation patterns induced in vitro by extracts from three rats treated with either DMSO (-) or z-DEVD-fmk $(+)$. The standard DNA fragments $(M W)$ represent a $1 \mathrm{~kb}$ DNA ladder.

whereas extracts from the homologous areas in the contralateral hemisphere or in sham-operated animals did not cause fragmentation of DNA in vitro.

To estimate the potential role of caspase-3-like proteases in trauma-mediated apoptosis more directly, we examined in vivo the effects of z-DEVD-fmk on the degree of DNA fragmentation and neurological recovery in rats subjected to TBI. This tetrapep- tide, when administered intracerebroventricularly, showed marked neuroprotective actions, as indicated by both improvement of neurological recovery and reduction of internucleosomal DNA fragmentation. Recently, Hara et al. (1997) showed that central administration of a caspase- 3 inhibitor, or caspase- 1 inhibitors, reduced infarct volume and neurological deficits in mice subjected to focal cerebral ischemia. Our present findings extend the observations of Hara and colleagues with respect to the protective effects of caspase- 3 inhibition to another injury model and species. In contrast to their findings in brain ischemia, the absence of increased ICE-like enzymatic activity after TBI suggests that the role of caspase- 1 in CNS injury may be modelspecific. However, it should be noted that caspase- 1 inhibitors such as z-YVAD-fmk may inhibit caspase-3 activity and associated apoptosis under certain experimental conditions (Eldadah et al., 1997).

We demonstrated that z-DEVD-fmk, even at high concentrations, was not able to affect the in vitro DNA fragmentation caused by extracts from traumatized cortex. However, extracts isolated from injured cortex and hippocampus of animals treated with this caspase-3 inhibitor demonstrated marked reduction of DNA cleavage activity. Taken together, these results suggest involvement of caspase-3-like proteases in post-traumatic apoptosis in brain, in part via activation of a downstream factor or factors causing DNA fragmentation. These observations are consistent with recent findings of Liu et al. (1997), who identified and cloned a new protein designated DNA fragmentation factor (DFF), which induces DNA fragmentation in isolated nuclei in vitro when activated by caspase-3; once cleaved by this caspase, DFF causes DNA fragmentation without a further requirement for caspase-3 or another cytosolic protein.

In summary, we have demonstrated the occurrence of apoptosis in selected brain regions after TBI, using both in vivo and in vitro methods, and have shown that such changes are correlated with the induction of caspase- 3 mRNA and activity. Moreover, central administration of a specific tetrapeptide inhibitor of caspase- 3 markedly attenuated apoptosis induced by TBI in vivo and improved neurological recovery after TBI. These results strongly implicate caspase-3-like proteases in neuronal apoptosis 
after TBI and suggest that inhibition of post-traumatic apoptosis has functional consequences, which may provide the basis for development of new therapeutic strategies for the treatment of CNS injury.

\section{REFERENCES}

Alnemri ES, Livingston DJ, Nicholson DW, Salvesen G, Thornberry NA, Wong WW, Yuang J (1996) Human ICE/CED-3 protease nomenclature. Cell 87:171.

Beilharz EJ, Williams CE, Dragunow M, Sirimanne ES, Gluckman PD (1995) Mechanisms of delayed cell death following hypoxic-ischemic injury in the immature rat: evidence for apoptosis during selective neuronal loss. Mol Brain Res 29:1-14.

Boldin MP, Goncharov TM, Goltsev YV, Wallach D (1996) Involvement of MACH, a novel MORT1/FADD-interacting protease, in Fas/ APO-1- and TNF receptor-induced cell death. Cell 85:803-815.

Boudreau N, Sympson CJ, Werb Z, Bissell MJ (1995) Suppression of ICE and apoptosis in mammary epithelial cells by extracellular matrix. Science 267:891-893.

Bredesen DE (1995) Neural apoptosis. Ann Neurol 38:839-851.

Bursch W, Kleine L, Tenniswood M (1990) The biochemistry of cell death by apoptosis. Biochem Cell Biol 68:1071-1074.

Buttini M, Appel K, Sauter A, Gebicke-Haerter PJ, Boddeke HW (1996) Expression of tumor necrosis factor alpha after focal cerebral ischaemia in the rat. Neuroscience 71:1-16.

Casciola-Rosen LA, Anhalt GJ, Rosen A (1995) DNA-dependent protein kinase is one of a subset of autoantigens specifically cleaved early during apoptosis. J Exp Med 182:1625-1634.

Chomczynski P, Sacchi N (1987) Single-step method of RNA isolation by acid guanidinium thiocyanate-phenol-chloroform extraction. Anal Biochem 162:156-159.

Clem RJ, Fechheimer M, Miller LK (1991) Prevention of apoptosis by a baculovirus gene during infection of insect cells. Science 254:1388-1390.

Cohen JJ (1993) Apoptosis. Immunol Today 14:126-130.

Compton MM (1992) A biochemical hallmark of apoptosis: internucleosomal degradation of the genome. Cancer Metastasis Rev 11:105-119.

Duan H, Chinnaiyan AM, Hudson PL, Wing JP, He W, Dixit V (1996) ICE-LAP3, a novel mammalian homologue of the Caenorhabditis elegans cell death protein Ced-3, is activated during Fas- and tumor necrosis factor-induced apoptosis. J Biol Chem 271:1621-1625.

Duffey DC, Calcaterra TC, Lichtenstein AK (1996) Regulation of transforming growth factor beta 1-mediated apoptosis in head and neck squamous cell carcinoma. Laryngoscope 106:889-894.

Eldadah BA, Yakovlev AG, Faden AI (1996) A new approach for the electrophoretic detection of apoptosis. Nucleic Acids Res 24:4092-4093.

Eldadah BA, Yakovlev AG, Faden AI (1997) The role of CED-3-related cysteine proteases in apoptosis of cerebellar granule cels. J Neurosci 17:6105-6113.

Enari M, Hase A, Nagata S (1995) Apoptosis by a cytosolic extract from Fas-activated cells. EMBO J 14:5201-5208.

Enari M, Talanian RV, Wong WW, Nagata S (1996) Sequential activation of ICE-like and CPP32-like proteases during Fas-mediated apoptosis. Nature 380:723-726.

Faden AI (1993) Comparison of single and combination drug treatment strategies in experimental brain trauma. J Neurotrauma 10:91-100.

Faden AI (1996) Pharmacological treatment of central nervous system trauma. Pharmacol Toxicol 78:12-17.

Faden AI, Demediuk P, Panter SS, Vink R (1989) The role of excitatory amino acids and NMDA receptors in traumatic brain injury. Science 44:798-800.

Fan L, Young PR, Barone FC, Feuerstein GZ, Smith DH, McIntosh TK (1996) Experimental brain injury induces differential expression of tumor necrosis factor-alpha mRNA in the CNS. Mol Brain Res 36:287-291.

Faucheu C, Diu A, Chan AW, Blanchet AM, Miossec C, Herve F, Collard-Dutilleul V, Gu Y, Aldape RA, Lippke JA (1995) A novel human protease similar to the interleukin-1 beta-converting enzyme induces apoptosis in transfected cells. EMBO J 14:1914-1922.

Faucheu C, Blanchet AM, Collard-Dutilleul V, Lalanne JL, Diu-Hercend A (1996) Identification of a cysteine protease closely related to interleukin-1 beta-converting enzyme (ICE). Eur J Biochem 236:207-213.
Fernandes-Alnemri T, Litwack G, Alnemri ES (1994) CPP32, a novel human apoptotic protein with homology to Caenorhabditis elegans cell death protein Ced-3 and mammalian interleukin-1 beta-converting enzyme. J Biol Chem 269:30761-30764.

Fernandes-Alnemri T, Litwack G, Alnemri ES (1995a) Mch2, a new member of the apoptotic Ced-3/Ice cysteine protease gene family. Cancer Res 55:2737-2742.

Fernandes-Alnemri T, Takahashi A, Armstrong R, Krebs J, Fritz L, Tomaselli KJ, Wang L, Yu Z, Croce CM, Salvesen G, Earnshaw WC, Litwack G, Alnemri ES (1995b) Mch3, a novel human apoptotic cysteine protease highly related to CPP32. Cancer Res 55:6045-6052.

Fernandes-Alnemri T, Armstrong RC, Krebs J, Srinivasula SM, Wang L, Bullrich F, Fritz LC, Trapani JA, Tomaselli KJ, Litwack G, Alnemri ES (1996) In vitro activation of CPP32 and Mch3 by Mch4, a novel human apoptotic cysteine protease containing two FADD-like domains. Proc Natl Acad Sci USA 93:7464-7469.

Gagliardini V, Fernandez PA, Lee RK, Drexler HC, Rotello RJ, Fishman MC, Yuan J (1994) Prevention of vertebrate neuronal death by the crmA gene. Science 263:826-828.

Glowinski J, Iversen LL (1966) Regional studies of catecholamines in the rat brain. I. The disposition of ${ }^{3} \mathrm{H}$-dopamine and ${ }^{3} \mathrm{H}$-DOPA in various regions of the brain. J Neurochem 13:655-669.

Hara H, Friedlander RM, Gagliardini V, Ayata C, Fink K, Huang Z, Shimizu-Sasamata M, Yuan J, Moskowitz MA (1997) Inhibition of interleukin-1 beta-converting enzyme family proteases reduces ischemic and exitotoxic neuronal damage. Proc Natl Acad Sci USA 94:2007-2012.

Hill IE, MacManus JP, Rasquinha I, Tuor UI (1995) DNA fragmentation indicative of apoptosis following unilateral cerebral hypoxiaischemia in the neonatal rat. Brain Res 676:398-403.

Islam N, Aftabuddin M, Moriwaki A, Hori Y (1995) Detection of DNA damage induced by apoptosis in the rat brain following incomplete ischemia. Neurosci Lett 188:159-162.

Iwai T, Hara A, Niwa M, Nozaki M, Uematsu T, Sakai N, Yamada H (1995) Temporal profile of nuclear DNA fragmentation in situ in gerbil hippocampus following transient forebrain ischemia. Brain Res 671:305-308.

Kamens J, Paskind M, Hugunin M, Talanian RV, Allen H, Banach D, Bump N, Hackett M, Johnston CG, Li P, Mankovich JA, Terranova M, Ghayur T (1995) Identification and characterization of Ich-2, a novel member of the IL-1 $\beta$-converting enzyme family of cysteine proteases. J Biol Chem 270:15250-15256.

Keane KM, Giegel DA, Lipinski WJ, Callahan MJ, Shivers BD (1995) Cloning, tissue expression, and regulation of rat interleukin-1 $\beta$ converting enzyme. Cytokine 7:105-110.

Kerr JFR, Wyllie AH, Currie AR (1972) Apoptosis: a basic biological phenomenon with wide-ranging implications in tissue kinetics. $\mathrm{Br} \mathrm{J}$ Cancer 26:239-257.

Kharlamov A, Uz T, Joo JY, Manev H (1996) Pharmacological characterization of apoptotic cell death in a model of photothrombotic brain injury in rats. Brain Res 734:1-9.

Kihara S, Shiraishi T, Nakagawa S, Toda K, Tabuchi K (1994) Visualization of DNA double strand breaks in the gerbil hippocampal CA1 following transient ischemia. Neurosci Lett 175:133-136.

Kuida K, Lippke JA, Ku G, Harding MW, Livingston DJ, Su MS, Flavell RA (1995) Altered cytokine export and apoptosis in mice deficient in interleukin-1 beta-converting enzyme. Science 267:2000-2003.

Kumar S, Kinoshita M, Noda M, Copeland NG, Jenkins NA (1994) Induction of apoptosis by the mouse Nedd2 gene, which encodes a protein similar to the product of the Caenorhabditis elegans cell death gene ced-3 and the mammalian IL-1 $\beta$-converting enzyme. Genes Dev 8:1613-1626.

Lazebnik YA, Cole S, Cooke CA, Nelson WG, Earnshaw WC (1993) Nuclear events of apoptosis in vitro in cell-free mitotic extracts: a model system for analysis of the active phase of apoptosis. J Cell Biol 123:7-22.

Li Y, Chopp M, Jiang N, Yao F, Zaloga C (1995a) Temporal profile of in situ DNA fragmentation after transient middle cerebral artery occlusion in the rat. J Cereb Blood Flow Metab 15:389-397.

Li Y, Chopp M, Jiang N, Zaloga C (1995b) In situ detection of DNA fragmentation after focal cerebral ischemia in mice. Mol Brain Res 28:164-168.

Linnik M, Zorrist RH, Hatfield MD (1993) Evidence supporting a role for programmed cell death in focal cerebral ischemia in rats. Stroke 24:2002-2009. 
Lippke JA, Gu Y, Sarnecki C, Caron PR, Su MS-S (1996) Identification and characterization of CPP32/Mch2 homolog 1 , a novel cysteine protease similar to CPP32. J Biol Chem 271:1825-1828.

Liu X, Zou H, Slaughter C, Wang X (1997) DFF, a heterodimeric protein that functions downstream of caspase-3 to trigger DNA fragmentation during apoptosis. Cell 89:175-184.

Los M, Van de Craen M, Penning LC, Schenk H, Westendorp M, Baeuerle PA, Droge W, Krammer PH, Fiers W, Schulze-Osthoff K (1995) Requirement of an ICE/CED-3 protease for Fas/APO-1mediated apoptosis. Nature 375:81-83.

MacManus JP, Buchan AM, Hill IE, Rasquinha I, Preston E (1993) Global ischemia can cause DNA fragmentation indicative of apoptosis in rat brain. Neurosci Lett 164:89-92.

Martin SJ, Green DR (1995) Protease activation during apoptosis: death by a thousand cuts? Cell 82:1-20.

Martin SJ, Newmeyer DD, Mathias S, Farschon DM, Wang HG, Reed JC, Kolesnick RN, Green DR (1995) Cell-free reconstitution of Fas-, UV radiation-, and ceramide-induced apoptosis. EMBO J 14:5191-5200.

Mashima T, Naito M, Fujita N, Noguchi K, Tsuruo T (1995) Identification of actin as a substrate of ICE and an ICE-like protease and involvement of an ICE-like protease but not ICE in VP-16-induced U937 apoptosis. Biochem Biophys Res Commun 217:1185-1192.

Masson M, Rolli V, Dantzer F, Trucco C, Schreiber V, Fribourg S, Molinete M, Ruf A, Miranda EA, Niedergang C (1995) Poly(ADPribose) polymerase: structure-function relationship. Biochimie 77:456-461.

McIntosh TK, Vink R, Noble L, Yamakami I, Fernyak S, Soares H, Faden AI (1989) Traumatic brain injury in the rat: characterization of a lateral fluid percussion model. Neuroscience 28:233-244.

Miller TM, Johnson Jr EM (1996) Metabolic and genetic analyses of apoptosis in potassium/serum-deprived rat cerebellar granule cells. J Neurosci 16:7487-7495.

Miura M, Zhu H, Rotello R, Hartwieg EA, Yuan J (1993) Induction of apoptosis in fibroblasts by IL- $1 \beta$-converting enzyme, a mammalian homolog of the C. elegans cell death gene ced-3. Cell 75:653-660.

Mogil RJ, Shi Y, Bissonnette RP, Bromley P, Yamaguchi I, Green DR (1994) Role of DNA fragmentation in T cell activation-induced apoptosis in vitro and in vivo. J Immunol 152:1674-1683.

Morozov VE, Falzon M, Anderson CW, Kuff EL (1994) DNAdependent protein kinase is activated by nicks and larger singlestranded gaps. J Biol Chem 269:16684-16688.

Munday NA, Vaillancourt JP, Ali A, Casano FJ, Miller DK, Molineaux SM, Yamin TT, Yu VL, Nicholson DW (1995) Molecular cloning and proapoptotic activity of ICErelII and ICErelIII members of the ICE/ CED-3 family of cysteine proteases. J Biol Chem 270:15870-15876.

Muzio M, Chinnaiyan AM, Kischkel FC, O'Rourke K, Shevchenko A, Ni J, Scaffidi C, Bretz JD, Zhang M, Gentz R, Mann M, Krammer PH, Peter ME, Dixit VM (1996) FLICE, a novel FADD-homologous ICE/ CED-3-like protease, is recruited to the CD95 (Fas/APO-1) deathinducing signaling complex. Cell 85:817-827.

Muzio M, Salvesen GS, Dixit VM (1997) FLICE induced apoptosis in a cell-free system. J Biol Chem 272:2952-2956.

Newmeyer DD, Wilson KL (1991) Egg extracts for nuclear import and nuclear assembly reactions. Methods Cell Biol 36:607-634.

Nicholson DW, Ali A, Thornberry NA, Vaillancourt JP, Ding CK, Gallant M, Gareau Y, Griffin PR, Labelle M, Lazebnik YA (1995) Identification and inhibition of the ICE/CED-3 protease necessary for mammalian apoptosis. Nature 376:37-43.

Rink A, Fung KM, Trojanowski JQ, Lee VM, Neugebauer E, McIntosh
TK (1995) Evidence of apoptotic cell death after experimental traumatic brain injury in the rat. Am J Pathol 147:1575-1583.

Satoh MS, Lindahl T (1992) Role of poly(ADP-ribose) formation and DNA repair. Nature 356:356-358.

Schulz JB, Weller M, Klockgether T (1996) Potassium deprivationinduced apoptosis of cerebellar granule neurons: a sequential requirement for new mRNA and protein synthesis, ICE-like protease activity, and reactive oxygen species. J Neurosci 16:4696-4706.

Schwartzman RA, Cidlowski JA (1993) Apoptosis: the biochemistry and molecular biology of programmed cell death. Endocr Rev 14:133-151.

Sei Y, Von Luitz DKJE, Basile AS, Borner MM, Lin RC-S, Skolnick P, Fossom LH (1994) Internucleosomal DNA fragmentation in gerbil hippocampus following forebrain ischemia. Neurosci Lett 171:179-182.

Shohami E, Novikov M, Bass R, Yamin A, Gallily R (1994) Closed head injury triggers early production of TNF $\alpha$ and IL-6 by brain tissue. J Cereb Blood Flow Metab 14:615-619.

Srinivasan A, Foster LM, Testa M-P, Ord T, Keane RW, Bredesen DE, Kayalar C (1996) Bcl-2 expression in neuronal cells blocks activation of ICE/CED-3 family proteases during apoptosis. J Neurosci 16:5654-5660.

Sun FY, Faden AI (1995) Neuroprotective effects of 619C89, a dosedependent sodium channel blocker, in rat traumatic brain injury. Brain Res 673:133-140.

Tewari M, Quan LT, O'Rourke K, Desnoyers S, Zeng Z, Beidler DR, Poirier GG, Salvesen GS, Dixit VM (1995) Yama/CPP32 beta, a mammalian homolog of CED-3, is a CrmA-inhibitable protease that cleaves the death substrate poly(ADP-ribose) polymerase. Cell 81:801-809.

Thornberry NA, Bull HG, Calaycay JR, Chapman KT, Howard AD, Kostura MJ, Miller DK, Molineaux SM, Weidner JR, Aunins J (1992) A novel heterodimeric cysteine protease is required for interleukin-1 beta processing in monocytes. Nature 356:768-774.

Trump BF, Bulger RE (1967) Studies of cellular injury in isolated flounder tubules. I. Correlation between morphology and function of control tubules and observations of autophagocytosis and mechanical cell damage. Lab Invest 16:453-482.

Trump BF, Berezesky IK, Cowley RA (1982) The cellular and subcellular characteristics of acute and chronic injury with emphasis on the role of calcium. In: Pathophysiology of shock, anoxia, and ischemia (Cowley RA, Trump BF, eds), pp 6-46. Baltimore, MD: Williams \& Wilkins.

Wang CX, Nuttin B, Heremans H, Dom R, Gybels J (1996) Production of tumor necrosis factor in spinal cord following traumatic injury in rats. J Neuroimmunol 69:151-156.

Wang L, Miura M, Bergeron L, Zhu H, Yuan J (1994) Ich-1, an ice/ced3 -related gene, encodes both positive and negative regulators of programmed cell death. Cell 78:739-750.

Wyllie AH (1980) Cell death: the significance of apoptosis. Int Rev Cytol 68:251-306.

Yakovlev AG, Faden AI (1994) Sequential expression of c-fos protooncogene, TNF- $\alpha$, and dynorphin gene expression in spinal cord following experimental traumatic injury. Mol Chem Neuropathol 23:179-190.

Yakovlev AG, Faden AI (1995) Molecular strategies in CNS injury. J Neurotrauma 12:767-777.

Yuan J, Shaham S, Ledoux S, Ellis HM, Horvitz HR (1993) The $C$. elegans cell death gene ced-3 encodes a protein similar to mammalian interleukin-1 $\beta$-converting enzyme. Cell 75:641-652. 